\title{
Ambition, Anxiety and Aspiration: the use and abuse of Cambridge University's Ten-Year Divinity Statute.
}

This paper examines the market for and motivation of those who made use of a little-known Cambridge University statute which, in effect, offered a low-cost distance learning degree until 1858. It shows how non-graduates, both clerical and lay, attempted to use its provisions to enhance their status, facilitate career advancement and insulate themselves against status slippage, a problem that became acute in the second decade of the nineteenth century as the reinvigorated universities reasserted their role as educators of the clergy and as the bishops increasingly denied ordination to those educated outside their sphere.

In doing so we can observe how the desires of non-graduate clergy to take degrees, and the attempts of liberally-educated non-graduates to enter the pulpits of the established Church, were responded to both by the university which received them and more broadly by the print discourse which critiqued their ambitions.

The tensions revealed are relevant not just for understanding something of how the clergy were developing as an occupational group, and the tensions caused by the changing supplies of graduates, but also reflect more generally the status anxieties of the elites and middling sorts as they faced down fears of competition for cultural and economic privilege appendant to educational opportunities.

\section{The ten-year divinity statute: interpretation and reputation.}

Distance learning has a long pedigree at Cambridge University. A papal dispensation allowing monks and friars to proceed to the degree of bachelor of divinity, without first taking a degree in the arts was, in spirit, to survive the reformation. Under the Elizabethan statutes of 1570, men aged over twenty-four, who had not graduated in the arts, were permitted to enrol for the bachelor of divinity degree, to which they could proceed after ten years of membership. ${ }^{1}$ It was from this requirement that these students gained their popular name 'ten-year men'. ${ }^{2}$ Although a requirement to reside might have been implicitly assumed it was not explicitly stated and indeed for most of the eighteenth century it appears that no minimum period of residence was enforced. D. A. Winstanley, historian of the university, gives the example of John Boutflower, who took the degree of B.D. in 1787 , for whom there is no evidence of residence. ${ }^{3}$ It may have been his example, as well as the realisation that increasing numbers of men were either being admitted to colleges or, more obviously, taking their degrees, ${ }^{4}$ which led to a 1788 ruling by the Heads of Houses that ten-year men should reside 'the greater part of three several terms' in the two years previous to proceeding to B.D., ${ }^{5}$ a requirement that lasted until the degree's abolition in 1858.

If the residence requirements were interpreted in a flexible way, so too were the necessary academic exercises. In theory these were identical to those required for the B.D. taken by the normal route, that is via B.A. and M.A. degrees. The major requirement was keeping a divinity act in the schools, followed by the delivery of two sermons in University Church, one in English and one in Latin. ${ }^{6}$ Whilst in theory challenging, the result of allowing men with limited access to books and no overall supervision or guidance in their studies to undergo the exercises seems to have been an admission that not much could be expected of them. In 1825 pamphleteer and Cambridge college member, Philotheologus, claimed that the materials needed to perform the exercises 'are, and may, be furnished ready cut and dried for the use of the candidate', but despite this ten-year men 
performed so poorly that undergraduates viewed the divinity school as a 'temple of fun and frolic'. ${ }^{7}$ From the same period John Martin Frederick Wright's Alma Mater, 1827, offered the story of a man returning from war with France who had enrolled himself as a ten-year man at Trinity Hall. Having associated with a 'gay-set', fixed on merry-making and cruel fun, this unprepared scholar was the centre of attention when performing his divinity act: 'At length the scene became so droll, and the mirth so indecorous that the Professor was constrained to pronounce aloud - Descendas', signifying failure and thus calling a halt to the proceedings. ${ }^{8}$ That undergraduates of the eighteen-twenties misprized ten-year men is confirmed by John Purcell Fitzgerald in his biography of ten-year man and Clapham sect associate, John Charlesworth: 'In our time of undergraduate ignorance, we used to look down with a kind of contempt on those who "came up" to College as "ten years' men". Their flowing sleeves, as we thought, covered their incapacity to pass one of our examinations. ${ }^{9}$

Modern scholarship has rarely noticed the ten-year man and when it has, it has adopted this negative assessment. ${ }^{10} \mathrm{It}$ is, then, worth noting a contemporary counter-view. The Morning Chronicle printed a letter in 1825 from a writer claiming to have been resident in college for almost twenty years, who asserted that the difference between ten-year men and regular university men was negligible. ${ }^{11}$ Biographical and bibliographical research shows that many were hardworking scholars before admission, that they often spent long hours in their studies whilst students, and that many were active, publishing scholars in later life. Before admission, Thomas Hartwell Horne's encyclopaedic knowledge of divinity literature had been demonstrated in his Introduction to the Critical Study and Knowledge of the Holy Scriptures (1818), a book which was recommended by bishops to ordinands. ${ }^{12}$ The value of Cornelius Bayley's Hebrew grammar, An Entrance into the Sacred Tongue (1778) had been recognised by the award of an honorary degree by the University of Edinburgh, before he entered Trinity College as ten-year man in $1781 .^{13}$ John Hewlett, admitted to Magdalene in 1786, published The Holy Bible ... with Critical, Philosophical and Explanatory Notes in 1812, a reviewer noting his work 'will ever remain a monument of Christian zeal and erudition. ${ }^{14}$ Examples could be multiplied many, many times of ten-year men and whose publication of sermons, devotional works, catechetical guides, Church of England polemic and speculative theology, show extensive reading, thought, and habits of scholarship.

The ten-year men also included those whose scholarship lay beyond the core focus of the English universities, their engagement in emerging academic fields perhaps a result of not having been habituated into the narrow scholastic world of undergraduate Oxford and Cambridge. There were a number of historians, antiquarians, philologists and scientists amongst their ranks. In the year he entered Cambridge as a ten-year man Joseph Bosworth published Elements of Anglo-Saxon Grammar. He finished his career as Rawlinson Professor of Anglo-Saxon at Oxford in $1858 .{ }^{15} \mathrm{John}$ Hellins had established a considerable reputation as a mathematician before he entered Trinity College in 1789 and was to be elected a fellow of the Royal Society while he was a student. ${ }^{16}$ William Scoresby, a prominent Arctic explorer and scientist, published voluminously and was a founding member of British Association for the Advancement of Science. ${ }^{17}$

The introduction of an additional examination for ten-year men, administered by the Regius Professor of Divinity, in the mid-eighteen twenties does suggest that the university recognised the weakness of the degree's assessment regime and attempted to implement some degree of quality control to bolster confidence, ${ }^{18}$ probably prompted by the 1825 publication of a critical pamphlet by an anonymous internal critic and the series of reviews, counter-claims and newspaper correspondence that followed it, to which we will come to later. But undergraduate assessment methods were, as a whole, undergoing reform during this period. ${ }^{19}$ Stiffer quality control may have been implemented but the ten-year degree was not singled out for remedial attention. 
In judging the abilities of ten-year men and perceptions of the degree we need, then, to be cautious. Contemporary interpretation of the statute meant that little was required of candidates, but a great many show a publishing track record that makes it clear that even if the university did little to support or encourage their studies, the award of a degree was not an inappropriate validation of skills and knowledge already possessed.

\section{Numbers of ten-year men}

About the first two centuries of the ten-year statute little can be discovered. If, as has been suggested, the seventeenth-century clergy almost all took degrees before ordination then there were few who could have benefited from its provisions excepting those far too poor to do so. ${ }^{20}$ Winstanley believed that the first man who actually proceeded to the degree was John Proudman who entered Jesus College as a fellow-commoner in 1708, and took a B.D. in $1719 .{ }^{21}$ From the latter part of the eighteenth century, however, the identities of ten-year men can be recovered using the Cambridge University Calendars, ${ }^{22}$ editions of Graduati Cantabrigienses, ${ }^{23}$ and Venn's, Alumni Cantabrigiensis. ${ }^{24}$ Over the period $1770-1858$ it is possible to recover 1,047 men who were entered under the ten-year statute, of whom 325 (31\%) were awarded a B.D. Charting the dates of entry shows that in the latter part of the eighteenth century there were just a handful of entrants, recruitment averages being just under eight men a year in the seventeen-seventies and eighties, falling to about four men a year in the seventeen-nineties, and increasing just slightly in the eighteen-hundreds. But thereafter admissions increased significantly: nine admissions in 1810, but thirty-four in 1819. During the period 1820-25 admissions peaked, the all time high being forty-one entrants in 1822. Although admissions dropped significantly from 1826, there were rarely fewer than ten a year and between 1844-1847 applications crept up again, reaching a peak of twenty-seven in 1847. After 1852, when it was clear that this route to a degree was about to be abolished, there seems to have been a brief revival and even in the final year admission was possible, 1858, nine men enrolled. ${ }^{25}$

Figures 1 and 2 chart admissions over this period, showing in addition the numbers who received B.D. degrees by this route in each given year, and the numbers of the entering cohorts who eventually went on to take B.D.s.

What then, can we make of the fluctuating popularity of this archaic and barely respectable distance learning degree? By taking a closer look at the types of men enrolling it becomes possible to gain a glimpse of how non-graduate clergy, and those who aspired to be in orders, tried to deal with their ambiguous status, not only to facilitate upward career mobility but also to defend themselves against status slippage or, to cast the dynamic process in Bourdieusian terms, to avoid becoming the losers in a 'classification struggle' in which educational status was being used as a symbolic boundary between different status groups within the clergy as a whole. ${ }^{26}$

\section{Who were the ten-year men?}

At the outset we need first to acknowledge that some recruitment ups and downs may result simply from changes in public knowledge about the degree. The ten-year route was not particularly widely known. Even at the peak of enrolment a Cambridge undergraduate might never encounter a tenyear man - they kept so little residence - and those who moved in Oxford-educated circles could have been totally ignorant. Indeed, Oxford-educated bishop of Winchester, Brownlow North (17811820), needed the matter explained to him when Joseph Bernard Burnett applied to him for orders in $1814 .{ }^{27}$ Thomas Scott's spur for entering in 1773 was simply that he had just heard that it was possible. ${ }^{28}$ Similarly, wider knowledge of the degree consequent on public debates about its termination probably account for the small increase in admissions in the degree's final years. 
But notwithstanding underlying fluctuations caused by levels of general knowledge about the statute, admission trends can be related more generally to the expectations and experiences of nongraduates, both those already in orders and those who aspired to them, and to the expectations of ordaining bishops. Clearly the popularity of this route to a degree, which increased significantly from 1813 , rising to an all time peak of recruits in 1822 , and which remained high until 1825 , needs some explanation.

Given the timing of the initial rise of admissions it is tempting to seek an immediate contributory cause in the end of war with France and the return of men looking for a new career. ${ }^{29}$ However, we need to be cautious. There were strong incentives to take orders only until December $1824,{ }^{30}$ but in the period 1815 to 1824 only seven men of about 288 new entrants under the statute can be identified as having had military careers, three of whom were ordained before taking university membership. ${ }^{31}$ Even if enrolling at Cambridge was a condition of ordination, a possibility we shall return to later, this was not something that specifically applied to ex-military candidates. Whilst the end of war did contribute to an increasing number of undergraduates reading for B.A.s, and thus led to increasing proportions of graduates in later ordination cohorts, it was not a major contributor to the increased popularity of the ten-year divinity degree. For that we must look elsewhere.

The ten-year divinity statute was intended to offer non-graduate clergy encouragement to enhance their theological learning by giving low-cost access to scholarly opportunities and by permitting formal validation of their achievements. That the minimum age of admittance was twenty-four points clearly to an assumption that they should have been in full orders (twenty-four being the minimum age for becoming a priest). However, just as the statute had not been explicit about residence, neither had it been explicit about the clerical status of the enrolling student and, as a result, it came to be used in ways that were far beyond the intent of its framers.

Certainly the requirement to preach sermons as part of the degree's formal exercises meant that a man had to be in orders before graduating. But did he have to be in orders when admitted ten years earlier? There was no clear consensus. In the first of the Cambridge University Calendars, we read that ten-year men are 'men that are in full orders. ${ }^{32}$ In 1802 we read that 'they are generally clergy, who having acquired wealth or preferment without a university education, dignify themselves at a moderate expense with an Academic Title' ${ }^{33}$ But the Calendars became increasing less clear, ${ }^{34}$ and in 1816 there was an exchange in the Gentleman's Magazine on the subject. ${ }^{35}$ In 1819 the humorous guide to Cambridge life, Alma Mater, informed intending students that 'Ten-year-men are so called because being admitted at college late in life, the Bishop immediately ordains them with the proviso that they reside at certain periods in the University, keep their names on the Boards, and keep certain Exercises in the Divinity Schools during ten years ...', but then adds, '... or perhaps it is otherwise derived. ${ }^{36}$

What then was the clerical status of those admitted? Overall it has been possible to establish accurate dates of ordinations and admittance for seventy-three per cent of the ten-year men entering 1770-1858. ${ }^{37}$ Of these, two-thirds were either deacons or priests before being admitted to college, the remaining third were admitted before being ordained. This probably overstates the total number of clerical entrants since amongst those whose ordination details have not been traced a disproportionate number will have been laymen.

Looking over the whole period, admission of laymen increased dramatically. Very rare in the seventeen-seventies and -eighties, they form a quarter of entrants 1800-9, and a third in the eighteen-tens and eighteen-twenties. Proportions peaked in the eighteen-forties when fifty-seven 
per cent of the new ten-year men were not already clergy. ${ }^{38}$ Such a division of clerical and lay entrants is, however, only partly helpful because there is a noticeable clustering of admission in the period around ordination. To draw out the purposes for which the degree was being used it is therefore useful make a threefold categorisation of entrants: established clergy seeking degrees; men entering around the period of their ordination, whose admittance and ordination seem in some sense to be linked; and aspirant laymen, who did not imminently expect a title for orders (that is an offer of clerical employment which was necessary before a bishop would offer ordination), and who did not have the agreement of a bishop to receive them, as undergraduate ordinands, once they had. ${ }^{39}$

\section{Distance learning for established clergy: ambition and anxiety}

The intended beneficiaries of the ten-year statute were non-graduate clergy unable to leave their parishes to keep the terms of university residence necessary to qualify for a B.A. Such men form about a third (34\%) of those men whose ordination and admission can be pinpointed accurately. Enrolment necessitated the expectation of some surplus income since college fees, although not extortionate, were still significant. ${ }^{40}$ Thomas Wilson, master of Clithero Grammar School, reflected that he had 'parted with his inheritance' to take his degree. ${ }^{41}$

Some men were motivated by the knowledge that their non-graduate status debarred them from preferment and advancement: men under the degree of M.A. were debarred by canon law from holding in plurality, that is increasing their incomes by holding more than one benefice simultaneously. ${ }^{42}$ The ten year interval between entry and graduating was too long to make definite plans but it certainly was a wise move for those who imagined that their talents, connections, or good fortune, might mean something on the horizon. Such ambition was encouraged by family, friends, patrons and diocesans. 'Expectation and desire of preferments and distinctions' motivated Thomas Scott in $1773 .{ }^{43}$ In the same year Thomas O'Beirne, an Irish Catholic convert and protégé of John Hinchliffe, bishop of Peterborough and Master of Trinity College, positioned himself well for future preferment by entering his patron's college as a ten-year man. Joining the English academic establishment proved a successful strategy, enabling him to be rewarded both for his talents, and by his influential connections. He became bishop of Ossory (1795), then Meath (1798) ${ }^{44}$

If some non-graduate clergy were motivated by hope and ambition, others were motivated by occupational unease. From the second decade of the century, as the universities began to expand, it seemed to many that the bishops should and would begin to reject non-graduates in favour of graduates. ${ }^{45}$ Fund-raising publicity for a projected clerical college for St David's diocese ${ }^{46}$ the opening of St Bees Clerical College, Cumberland, in 1817, ${ }^{47}$ and a succession of episcopal charges exhorting clergy to keep up with the rising standard of general education, ${ }^{48}$ reinforced impressions that the educational and intellectual capacities of existing non-graduate clergy were insufficient for present and future needs. In 1825 the bishops of the northern province, where non-graduates had previously been ordained in significant numbers, announced a future intention to accept only graduates or those educated at St Bees College. ${ }^{49}$ This was to prove an overambitious aim, but it did not seem so at the time and a strong message was sent out that in future access to the pulpits of the established Church, and the livelihood she could offer, lay through the universities of Oxford, Cambridge and (sometimes rather grudgingly) Dublin or, failing sufficient supply and the necessity to admit non-graduates, St Bees College. ${ }^{50}$

In this context non-graduate clergy had concerns that went further than a foreboding that younger, more highly qualified men in the up-coming generation would outcompete them. In 1830 William Snowden, a non-graduate clergyman from Yorkshire, authorised by archbishop Venables Vernon to 
prepare non-graduates for orders and who had an extensive network of ex-student informants, published a defence of the character and utility of non-graduate clergyman. Snowden believed that there was a real risk that bishops would move from not ordaining non-graduates to not licencing those already ordained to curacies or instituting them to benefices. He understood there had been such threats in Gloucester diocese in $1827 .{ }^{51}$ And there is independent evidence that these fears were not unfounded: in the same year, bishop Kaye of Lincoln refused to allow a non-graduate a curate's licence..$^{52}$ It would be unsurprising if, in these circumstances, a fear of being trapped in lowvalue employment or of being unable to find any employment at all led some non-graduate clergy to fix on the ten-year route as the most affordable remedy for their ills. William Snowden himself had done just that, entering St Catharine's College, Cambridge, in $1827 .{ }^{53}$ There is even evidence of career insecurity even amongst those who held formal professional qualifications from the two clerical colleges for non-graduates at St Bees (opened 1817), and St David's College, Lampeter (opened 1827), whose students were not welcome in all dioceses. ${ }^{54} \mathrm{~A}$ number enrolled at Cambridge on the ten-year route to B.D. after ordination. ${ }^{55}$

On the face of it, the rapid downturn in ten-year admissions after 1825 would, however, seem to argue against career anxiety as an explanation for increasing enrolment of clergy under the ten-year statute. Things did not get any better in 1825 - in fact the northern province bishops' statement about raising the qualification bar in that year only further clouded their horizons. The answer lies, however, in the public trouncing of the degree in 1825 which came in the wake of pamphlet published by St John's student Samuel Perry, in which he revealed how the ten-year route to B.D. had proved a personal dead-end. ${ }^{56}$ Perry's predicament we shall return to later, but at this point, by looking at the reviews and responses provoked by his pamphlet we can understand more about how the dominant discourse about non-graduate and low-born clergy played a role in increasing social and occupational anxiety amongst liberally-educated non-graduates who were operating at the fluid lower margins of professional and genteel worlds, and who were conscious of the danger of being re-classified out of them.

There was nothing new in the claim that graduate clergy had a natural right to enjoy the Church's cultural and economic capital. Canon law, in permitting only those with M.A. degrees and higher to hold more than one benefice, had given advantage to those whose scholarship was assumed to be superior, ${ }^{57}$ the concession based on an assumption that the prospect of material rewards would encourage men to engage in those university-based studies deemed necessary for an effective preaching ministry and for the defence of the faith. But it also came to encode proprietorial claims to the Church's wealth grounded in superior social and economic status, since to proceed to M.A. required extra investment of time and money. ${ }^{58}$ This sometimes finds explicit articulation, for instance in assertions that those who had expended most on their education were entitled to preferential employment and maintenance. In 1825 the Gentleman's Magazine noted, 'it is certainly hard that a man who earned his trifling portion of Latin and Greek at a day-school of fourpence a week, should obtain the same pecuniary benefits, as he whose education at school and the University has cost one thousand pounds. ${ }^{59}$ In this vein came praise for Bishop Blomfield of Chester who, in deciding never to ordain a non-graduate if a graduate was available, could be described as acting to 'protect the rights of graduates. ${ }^{60}$

But notwithstanding the claim that a graduate's superiority was axiomatic and clearly distinguished him from non-gradates in terms of learning, behaviour and professional utility, the universities were themselves not without anxiety. In particular, Cambridge University was on shaky ground when it claimed the superior quality of its graduates in terms of clerically useful learning and skills. Not only did its mathematics-focussed curriculum give little time or encouragement to studies which might 
have assisted students to prepare for ordination or given them skills useful for their subsequent occupation, it was understood in some circles that at diocesan ordination examinations, nongraduates - educated in grammar schools, by tutors and by self-directed reading - would often demonstrate a better knowledge of divinity and more facility with Greek and Latin translation, than Cambridge graduates. ${ }^{61}$ But whilst Cambridge University acknowledged that there were longstanding, serious issues concerning the mismatch between curriculum, discipline, assessment and the entry requirements for the clerical occupation, only slow progress was made with putting its house in order in this period. ${ }^{62}$ Much greater success was achieved by broadcasting polemical assertions of the cultural and social superiority of the graduate. University men were not slow to reach for the pen in defence of their alma mater and the reputation of their own expensive educations.

It is telling then, that whilst the qualitative superiority of graduates clergy is deemed self-evident, paradoxically the bishops were also called on to actively discriminate in their favour. Dioceses where non-graduates were excluded by policy, were approved. ${ }^{63}$ It was proposed that if non-graduates were ordained they should be confined to their dioceses of ordination or prevented from taking preferment, ${ }^{64}$ although it was acknowledged that they might be allowed a colonial career, since graduate clergy were generally reluctant to take such unpopular posts. ${ }^{65}$ The desire to make absolutely clear the distinction between graduate and non-graduate, with the implied fear that confusion might otherwise occur, is shown in a letter published in the Gentleman's Magazine in 1819, about the necessity of being able to distinguish them by their vestments: non-graduates should wear tippets only (but not of silk) but not an academic hood. ${ }^{66}$ Without such discriminatory policies there seems to have been an underlying fear that if judged solely on their preaching and pastoral ministries, the self-evident inferiority of such men may have gone unnoticed by those who received their ministries and offered them preferment.

Justifications for such discrimination were rooted in the conviction that the existing social order was divinely ordained and functioned to keep the nation from the civil disorder which would inevitably result if the lower orders began to desire and obtain the privileges providentially allotted to their social superiors. It was not that the established Church rejected on principle the idea that natural ability and hard work should be rewarded or that families might not attempt to inch their way up the social hierarchy by educating their children for a higher station. Indeed, extraordinary examples of hyper-mobility were high-lighted as demonstrating both God's grace and the Church's ability to recognise this and reward merit, ${ }^{67}$ and that some members of the episcopate in the late eighteenth and early nineteenth century had risen from relatively humble backgrounds, gave further support to an impression that the Church was an open elite ${ }^{68}$ However, as Gibson noted with regard to the nineteenth-century episcopate, 'meritocracy for the Victorian Church meant a meritocracy of the middle class': ${ }^{69}$ it was one thing to acknowledge that exceptional merit should be rewarded and quite another to see men of lower social origins and poorer backgrounds successfully competing for the limited resources that the Church could provide, driving down curates' salaries and diluting occupational prestige. As such, the animosity shown to those who had achieved, or where trying to achieve, cultural uplift into the respectable ranks of the clergy, without the transformative change in habitus which the universities offered, can be seen more broadly as part of the defence of the social, cultural and economic hegemony of the university-affording classes. This is an anxiety better recognized in the Victorian period, ${ }^{70}$ but, its basic mode of operation - denying the moral, intellectual or cultural worth or aptitudes of small tradesmen, skilled artisans, clerks and schoolteachers, and asserting that those who had paid most for their education were entitled to higher occupational earnings - was clearly well established in the late Georgian period. 
In print, clergy who had taken orders without passing through Oxford or Cambridge, except for those whose elite social status was abundantly clear, usually received a verbal horse-whipping. They were characterised as ignorant, incompetent and prone to a moral laxity which was the corollary of their inferior social origins. In 1815 a correspondent to the Gentleman's Magazine, whose core readership of self-defined gentlemen included a great many clergy, described 'little schoolmasters and such like', who took orders, as 'pitiable objects (more fit to make a pulpit than to get into one). ${ }^{71}$ In 1819 a correspondent to the same magazine, who identified as a member of Oxford University, recycled an anonymous 1783 description of non-graduates as 'puffed up' sons of the peasantry, 'unencumbered with the dignity of birth, genius or learning.' 72 In 1825 Cambridge member Philotheologus, critic of the ten-year statute, referred to their aspirations in terms of impudence and pretence, bolstering his point by alleging that they had previously been in low-status occupations, as blanket-weavers, curriers [tanners], linen-drapers, shopmen and porters. ${ }^{73} \mathrm{~A}$ reviewer concurred, claiming that non-graduate clergy were commonly horse-dealers (an occupation associated with sharp-practice) and gesturing to the widely held belief that tradesmen and labourers should have been excluded from orders on canonical grounds. ${ }^{74} \mathrm{~A}$ correspondent to the Morning Chronicle used the recent example of felonious cleric Abraham Charles Mummery (who it alleged, erroneously, had been a ten-year man), to demonstrate that the statute was 'indecent' because it claimed 'men of all sects, ranks and characters, and qualification, for better or worse. ${ }^{75}$

The problem with these 'anomalous non-descripts', as Philotheologus had termed them, ${ }^{76}$ was not, however, their artisan or trade origins (university graduates who had been fortunate enough to qualify for scholarships or attract patronage still continued to spring from such stock), nor indeed their educational insufficiency - as we have seen many non-graduates could compete very well in terms of professional skills, and in wider cultural fields. Their real offence was that their admission to orders had not been mediated through the universities, using the apparatus of endowed scholarships and fellowships, bestowed on those boys most apt to acquire new dispositions and thus most easily absorbed into elite society. Whilst the universities' underperformance had, in the past, necessitate the ordination of those who were educated and socialised outside this system, in their newly energized state, in which it seemed for a brief period that they would have the capacity to provide enough graduates to supply all clerical needs, they asserted a right to control entry to the Church - to act as gatekeeper to its political, economic, cultural and spiritual resources. And the print discourse concerning non-graduate clergy was one site at which the universities and college members policed this privilege. The venom would continue to flair up occasionally, ${ }^{77}$ but alternative discourses which presented the advantages to the Church of England's pastoral and socio-political mission which would result from the recruitment of men from broader social backgrounds, would be aired more frequently. The century would see attempts at self-improvement come to be recognised as individual virtue which had a positive impact on society as a whole, rather than a personal vanity that potentially destabilised the social order. ${ }^{78}$ The concept of a gentleman would be recast to give value to character and conduct rather than simply wealth and bloodlines, ${ }^{79}$ and the idea that the Church's social selectiveness was in fact a damaging 'heresy', especially in the context of an increasing need for manpower which the universities were finally admitted to be incapable of supplying, would find articulation, ${ }^{80}$ even if most many pastoral commentators, still wedded to a ideal of a clergy who shared the dispositions of the elite, continued to defended an Oxbridge education as a professional desideratum. ${ }^{81}$

\section{University membership as a condition of ordination}

If the ten-year statute had been intended to benefit the non-graduate clergyman who were already in priests' orders, then it is also clear that, on occasions, enrolling was also a strategy used by men 
who were at the very opening of their clerical lives. An examination of the interval between admission to Cambridge as a ten-year man and ordination reveals a distinct clustering of men whose ordination and university admission are very closely associated. For the whole period, such men form forty-seven per cent of those whose admission and ordination can be dated. In some instances the timing is so close that it is hard to doubt that the two events were not linked. William Hutchinson was admitted to college four days before he was ordained deacon in March 1823. Thomas Gregory was admitted the day after his ordination as deacon in 1822. John Curtis was admitted to Trinity College the day after he was ordained priest in 1817.82

In many instances, especially where entry was several months before ordination - before the usual time of formal application to a bishop for ordination - entering university was probably an attempt to impress a prospective diocesan who was known to favour university education but who would sometimes ordain undergraduates. Perhaps, on occasions, it was even hoped that the bishop would not enquire to closely and assume that they were undergraduates reading for a B.A. and due to graduate in a matter of months rather than years. But where the intervals are very close one suspects strongly the direct influence of a bishop. On a rare occasion it can be proved to have been a condition of ordination. When, in 1819, William Howley, bishop of London, deviated from his usual rule of admitting only graduates by ordaining Thomas Hartwell Horne, it was conditional on him joining St John's College, Cambridge. ${ }^{83}$ It seems possible that other bishops made university membership either a condition of ordination or of progressing to the priesthood, or if not a condition, at least encouraged it. Inevitably, most ten-year men of this type came from those large dioceses which admitted the greatest numbers of non-graduates, in particular York and Chester. But occasionally in the smaller dioceses there are unexpected numbers of men of this type. At Rochester, of the six men ordained by bishop Walker King in 1822, two were ten-year men: James Pearson was admitted a couple of weeks before ordination and William Owen's admission was actually recorded the same day he was ordained. ${ }^{84} \mathrm{King}$, it seems, would occasionally ordain a nongraduate but preferred them to be university members. It is difficult to push the matter much further - the conversations between those on the verge of taking orders and their prospective diocesans, and the 'gentleman's agreements' and conditions imposed upon the ordinands - leave little trace in ordination-related administrative records. The fact that so very many of those who entered themselves for the ten-year B.D. at Cambridge were also just about to, or just had, taken orders, does strongly suggest, however, that the events were procedurally associated.

\section{Aspiring to holy orders}

The period after 1810 saw a new type of ten-year man become increasingly common. Taking advantage of the ambiguity of the statute with regard to clerical status, increasing numbers of laymen entered who seem to have had no immediate expectations of ordination. Rare before $1811,{ }^{85}$ after this point they became both numerically and proportionately significant forming about one in five of the entrants whose dates of admittance and ordination are known 1810-1829 and between a quarter to a third between 1830-1858. In the eighteen-forties they outnumbered entrants who were established clergymen. ${ }^{86} \mathrm{It}$ is likely that such men actually formed a much greater proportion of entrants since they are likely to have been the majority of those whose dates of ordination have not been found quite simply because they were never ordained.

The growth in this type of entrant may well have been encouraged by the colleges themselves. These students offered the colleges increased fee income with no corresponding increase in tutorial work or responsibility. Essex schoolmaster Samuel Perry, who had been admitted to St John's College intending to take a B.A., was directed to the ten-year route by his college tutor. ${ }^{87}$ There was 
also some active encouragement of aspirant laymen by bishops. It was suggested to George Atkinson by Henry Ryder (bishop of Lichfield, 1824-36) ${ }^{88}$ and to John Henry Matthiason, probably by bishop Kaye of Lincoln. ${ }^{89}$

The colleges were probably motivated by financial rather than political concerns. Arthur QuillerCouch's suggestion that in admitting ten-year men the colleges were attempting to increase their share of the electorate to the Lady Margaret Chair in Divinity, is appealing but probably incorrect since electors were required not only to have a divinity degree but also to have acted as regent masters, that is to have resided and taught in the university after taking their M.A.s., which ten-year men had not. ${ }^{90}$ Whilst one might suppose some internal opposition to such a recruitment strategy in those colleges were fellows were obliged to take B.D.s through the ordinary route, on the grounds that the degree was being devalued, there is limited evidence of this. ${ }^{91}$ College fee regimes may indicate attempts to deter ten-year men at Peterhouse and Magdalen, where ten-year fees were not only high but higher than for the standard B.D., and at Trinity College, where fees were raised substantially after $1826 .{ }^{92}$ But low fees elsewhere, particularly Trinity College (before 1826), Queens' College and St John's College suggest that ten-year men, in general, were welcome, even where fellows were also required to take B.D.s via the usual route. ${ }^{93} \mathrm{At}$ at least one college there were concerns about the use to which the statute was being put. In 1812 Trinity College resolved to restrict entry to the traditional type of student - those already in orders - but they did not adhere strictly to this decision, and continued to admit laymen, until $1826 .{ }^{94}$ At Queens and St John's colleges laymen continued to be admitted throughout the period. ${ }^{95}$

In welcoming this type of student, the colleges were responding to a demand from young men who were finding that the plans made for them by their parents and the aspirations they had for their own future careers had been undermined by the recent disruption of traditional routes of nongraduate entry to the Church. In the late eighteenth century and first decade of the nineteenth century it was possible for parents, especially in Wales and the northern province, to place a son in the Church using the well established route of specialist grammar schools and clerical tutors, without incurring the expense of university. ${ }^{96}$ However, as the universities expanded and bishops increasingly favoured graduates ordinands, non-graduates struggled to find a way into the Church. The usual fall-back occupation was the quasi-clerical occupation of school teaching, a type of employment that most bishops would permit prior to ordination to those men unable to support themselves without employment until they were old enough to take orders. But whether teaching was a stop-gap whilst seeking orders, or was adopted as a substitute profession in lieu of entering the Church, these men would still have encountered a major impediment to career advancement. Many grammar schools had statutes which required their masters to have degrees or to be in orders. John Skinner told the bishop of Lincoln in 1833 that he had been rejected as an applicant for the mastership of Caistor Grammar School for this reason. He wondered if the ten-year route might help him achieve his aim of becoming a headmaster of a 'public school'. ${ }^{97}$ And it is possible that that Samuel Perry, a schoolmaster from Shenfield, Essex, felt his career opportunities similarly restricted. Had he, for instance, had his sights set on the mastership of the nearby Brentford Free Grammar School, with its house, garden, six acres of land and residual profits, he would have needed to be in full orders. ${ }^{98}$

\section{Samuel Perry's predicament}

In growing this area of university business there was an element of risk since by admitting laymen who had no certain expectations of ordination, it became possible that a student would come to the end of ten years and be unable to complete the sermon requirement of the academic exercises 
because he was not in orders. And he would not be in orders because he had not been able to find a title under a bishop who would ordain an undergraduate. It was this catch-22 situation that Samuel Perry found himself in when in 1824 William Howley, bishop of London, rejected him as an ordination candidate because he had no degree. ${ }^{99}$

It not possibly to say with any degree of certainty how many men found themselves in Samuel Perry's situation. Amongst those who did not take their B.D.s were surely many who did not proceed because of financial or domestic constraints, or because another degree had been acquired in the meantime, or because they had died. Overall we can name 177 laymen men who entered 1770-1858 who appear to have been unsuccessful in their aims. The numbers of such men start increasing from the cohorts admitted in the late eighteen-tens, with the peak periods for not proceeding to B.D. being the eighteen-twenties and eighteen-forties. ${ }^{100}$ Of Perry's cohort who entered in 1814 only three out of fourteen were not already in orders, and of these only Perry was ultimately unsuccessful. ${ }^{101}$ But Perry was not unique; St John's had many unsuccessful aspirants over the broader period, ${ }^{102}$ and others seem to have had to wait, on occasions, much longer than ten years to find a title and co-operative bishop: ${ }^{103}$ Augustus lons who had entered in 1811 was not ordained until $1825 .{ }^{104}$

There are signs that some students were aware that the ten-year plan was a somewhat precarious one even before Perry had published his complaint. A number, having entered as ten-year men, actually went on to take B.A.s or enrol for law degrees. ${ }^{105}$ Others also enrolled at St Bees College which, if not degree-granting, at least gave a formal qualification recognised in some dioceses. ${ }^{106}$ Men trying to obtain ordination, without taking a B.A. degree, seem to have tried numerous strategies to qualify themselves in the eyes of prospective bishops.

Despite the fact that a predicament like Perry's might easily have been predicted by those colleges who were stretching the interpretation of the statute to welcomed aspirant clergy, Perry did not see himself as having been mis-sold his education. ${ }^{107}$ Instead he interpreted his rejection as a result of the inconsistent and unjust actions of bishop Howley. In this he was wide of the mark: the London ordination records show that his rejection was entirely consistent with Howley's domestic policy. ${ }^{108}$ But more generally Perry could expect that some of his readers would accept his diagnosis of episcopal inconsistency and peremptory behaviour. Non-graduate clergy, their friends and the public at large were aware that bishops had widely divergent ordination policies, and that some of them applied idiosyncratic interpretations of canon law. ${ }^{109}$

But Perry's published protests - he was subsequently to demonstrate a monomania on the subject of ten-year statute ${ }^{110}$ - achieved little personally for him. As the Quarterly Theological Review put it 'had he conducted himself with more moderation, he might have found many inclined to interest themselves in his case'. ${ }^{111}$ And indeed, since bishop Howley became archbishop of Canterbury in 1828, Perry's criticisms became even more unwise. Unsurprisingly, he was never ordained but remained in Shenfield, running a small school and supporting a large family, ${ }^{112}$ personal occupational and social aspirations unfulfilled and still troubled by his status: on his will drawn up in 1844 he had crossed through 'schoolmaster' and inserted 'gentleman.' ${ }^{113}$ Two of his sons, however, would succeed where he had not, entering the Church via the safe route of university. ${ }^{114}$

\section{End of the degree}

Despite drawing attention to the frailty of the ten-year divinity statute as a passport to orders, the Perry affair did not see the end of applicants. Notwithstanding a low academic reputation, not only did established clergy continued to enrol (significant numbers of non-graduate clergy were again 
being ordained by the eighteen-fifties), some bishops continued to recommend it to ordinands, ${ }^{115}$ and those with clerical pipe dreams still tried their luck. The numbers of entrants may have dipped after 1825 but they recovered reasonably well. In 1836 Samuel Perry went as far as to suggest that if a similar statute was introduced at Oxford and Dublin, bishops would be able to require all nongraduates trained at St Bees, St David's and Durham University, to take distance learning degrees after ordination. ${ }^{116}$ In the following year the Political Examiner suggested that, if the bishops could not be prevailed upon to cease insisting that older ordinands took degrees, then an extension of the ten-year man principle to Oxford also would have merit. ${ }^{117}$

At Cambridge, as new methods of assessment superseded the old academic exercises, and pressure for reform grew, the old B.D. could not survive. It could, however, have been adapted. In 1841 George Peacock's proposals for university reform suggested that the ten-year route might, perhaps, be retained by keeping the existing exam in classical literature and divinity but abolishing the divinity act in the schools. ${ }^{118}$ The university syndicate appointed to consider reform of the statutes recommended abolition of the degree in Feb. 1852, a decision endorsed, with some reluctance, by the Royal Commissioners later the same year. ${ }^{119}$ In the context of the mood of the 'age of reform', typified by a discourse of raising standards, doing away with unmerited privilege, and imposing consistency in process, it is, on the face of it, unsurprising that the ten-year route to B.D., with its muddled admission and assessment criteria and poor academic reputation, was deemed fit to be reformed away. What is interesting is that the desire to abolish it, rather than adapt it, came most strongly from within the university, usually understood to have dragged its feet and to have embraced only those reforms which essentially supported the status quo and maintained the existing privileges of the colleges and the established church. The Royal Commissioners, who worked with more advanced reforming impulses, instead showed themselves to have understood the useful role the ten-year statute had played, reporting: 'The privilege itself may be regarded as an anomaly in the Academical system; but as it afforded the means of gratifying a class of respectable men and attaching them to the University, we look upon the proposal to abolish it with some feelings of regret'. ${ }^{120}$ In some senses the ten-year route to a degree for non-resident mature students seems to have been more of a thorn in the side of conservative university elements than to those who envisaged a broader role for the ancient universities. The new statutes of 1858 , then, terminated this little-known Cambridge degree, although in actual fact ten-year men were to linger. The final one was Rev Samuel Andrew, admitted to St John's in 1856 a couple of years after his ordination, who remained on the boards until his death in $1900 .^{121}$

In the place of the B.D. the University proposed to introduce a licentiate in theology, following the precedent set by Durham University and King's College London in offering sub-degree level theological qualifications. ${ }^{122}$ But they purposed to disallow licentiates' terms to count against B.A. degrees, drawing a line between licentiate and bachelor which would be almost impossible to cross. The Commissioners were to object to and overrule this, ${ }^{123}$ but it demonstrates that whilst the currents of meritocracy may have been moving strongly in some directions, evidenced by the Commissioners' concerns about costs of university education and the preferential claims some schools had over endowments, ${ }^{124}$ there were strong counter-currents resisting the status dilution which would result from granting more degrees to men from the lower ranks of society. The same issues were playing out in the reforms of non-graduate higher-education elsewhere. St David's College, Lampeter, anxious to enhance its institutional status, gained the right to award the degree of B.D. to its non-graduate alumni in $1852 .{ }^{125}$ But whilst the Welsh college was keen to acquire social and professional status for its students, so shaky was the reputation of the university at Durham that in 1861 it rebuffed a petition for a similar scheme from its licentiates in theology, unwilling to be 
seen to grant degrees too easily. ${ }^{126}$ As the century progressed the clergy would become a body who had, almost without exception, undertaken formal higher education, either at a university or at a specialist theological college, but the line between graduate and non-graduate continued to be a matter of great social and professional significance. Whilst Convocations and Church Congresses would acknowledge the importance of alternative educational provisions, overall recruitment success was still measured in terms of proportions of ordinands who had been educated at Oxford and Cambridge, despite the fact they might still present themselves for ordination without any professional preparation for their future occupation. The rest, whose studies had been focussed directly on their future roles, continued to operate under a dominant discourse that understood them as inferior but necessary whilst there were insufficient Oxbridge men wanting to take orders, and very useful for certain kinds of ministries overseas and with the lower classes. ${ }^{127}$

\section{Conclusion}

The ten-year statute gave Cambridge University a role in the professional development of nongraduate clergy. The massive increase in clerical enrolments under the statute after 1813 resulted from a growing anxiety on the part of non-graduate clergy about potential restrictions on future promotion and employment. The increasing admission of laymen came about as those who had received their liberal educations outside the universities increasingly understood that their career options were limited, both in terms of entering the Church and in terms of teaching careers. Whilst some colleges seem to have welcomed these extra students, pamphlet and periodical responses to the increasing numbers of ten-year men, which overtly complain of the low standard of the degree, reveal a discomfort with the porosity of the lower boundary of the clerical order, and signal that the statute was perceived as a threat to graduate status, since it allowed men whose families lacked the means to fund university education in adolescence to enjoy a lower-cost form of university membership in adulthood, and as a threat to elite status of the graduate clergy if non-graduates were permitted to compete on a level playing field for ordination and preferment.

These anxieties about who should have the rights of access to educational resources, cultural opportunities and their appendant occupational privileges were played out repeatedly in early and mid-nineteenth century educational politics, not just in terms of debates about the education appropriate for the clergy but more generally as the English and Scottish universities jousted over academic standards and admission profiles; ${ }^{128}$ non-Anglicans demanded access to the privileges of Oxford and Cambridge with increasing force; ${ }^{129}$ and those grammar school and university endowments, that had once offered clever boys from poorer families a liberal education and the possibility of matching occupational opportunities, were increasing appropriated by the middle and upper classes and replaced by a system of stratified education based upon a child's social origins and its parent's ability to pay. ${ }^{130}$ The Church might continue to laud the examples of men who had risen to prominence from humble origins, and the universities might express a commitment to reward merit, but men of lower social status with lower-cost, lower prestige educations were the losers of a classificatory war, placed in a category deemed inferior, with few practical ways to improve their standing. Non-graduate clergy would remained anxious and their ambitions and aspirations would remain an issue for the Church of England. With the passing of the ten-year statute, they lost an effectual method of remedying their ills. 
${ }^{1}$ For a summary of earlier statutes see George Peacock, Observations on the Statutes of the University of Cambridge (1841), xlvi (an error for xlvii)-xlviii, n. 1. The ten-year statute forms chapter 9 of the statutes, George Dyer, Privileges of the University of Cambridge, (2 vols., 1824), i. 166.

${ }^{2}$ Less frequently 'twenty-four men', a reference to their minimum age.

${ }^{3}$ Dyer, i. 290-1; D.A. Winstanley, Unreformed Cambridge (Cambridge, 1935), pp.69-70, 355 n.95.

${ }^{4}$ Winstanley, Unreformed Cambridge, pp.69-70. Given that non-resident ten-year men were inconspicuous it seems likely that it was the increasing numbers proceeding to B.D. which raised their profile. Only 4 took B.D.s $1770-1779$, but 19 in the following decade. In 1782, 1783, 1784, 1787 they matched or exceeded the numbers of regular B.D.s, Joseph Romilly, Graduati Cantabrigienses (Cambridge, 1846), Tabula Graduum, pp.426-9.

${ }^{5}$ Winstanley, Unreformed Cambridge, pp.69-70; Adam Wall, An Account of the Different Ceremonies Observed in the Senate House of the University of Cambridge (Cambridge, 1798), pp.120-1.

${ }^{6}$ Divinity acts were public performances given in Latin in which a candidate proposed questions and defended a thesis against three opponents, one of whom should have been a doctor of divinity. They were moderated by the Regius Professor in Divinity. For a fuller description of the exercises see Peter Searby, A History of the University of Cambridge, vol. 3: 1750-1870 (Cambridge, 1997), pp.262-3.

${ }^{7} \mathrm{He}$ admits, however, that 'some few' of them 'would be an honour to any University', Philotheologus, $A$ Letter to John Lord Bishop of Bristol ... respecting an additional examination or total abolition of the ten-yearman. (Cambridge, 1825), pp.12-16.

${ }^{8}$ A Trinity-Man [John Martin Frederick Wright], Alma Mater or Seven Years at the University of Cambridge (2 vols, 1827), ii. 125-9. Assuming a kernel of truth, this event dates to 1820-21 (Regius Professor Kaye was bishop of Gloucester 1820-27, and esquire bedell John Beverley was in post 1770-1827, but inactive from 1821 (H.P. Stokes, The Esquire Bedells (Cambridge, 1911), pp.113-4)). Admission must then date to c.1810-11 at the latest. If a real person, rather than a composite character, there are few likely candidates: David Felix (admitted 1811, B.D. in 1822), Paul Siddall (admitted 1812, no B.D.) and George Bailey Tuson (admitted 1815, B.D. 1825). The best match is Felix, but I have not been able to uncover any previous military career - he had been a classical assistant some years before ordination (York, Borthwick Institute for Archives, University of York (B.I.), Ord.P. 1814). Tuson was captain in the East Somerset Regiment of Volunteers in 1808 (Royal Military Chronicle, 4 (1811), 242), but there is no evidence he served oversees with the regular army and it is unlikely Beverly attended his act in 1825. I have found no military links for Siddall. 
9 John Purcell Fitz-gerald, The Quiet Worker for Good: a familiar sketch of the late John Charlesworth (1865), pp.61-2. Fitz-gerald (also Fitzgerald) was an undergraduate 1822-26.

${ }^{10}$ D.A. Winstanley's discussion of the ten-year men, Unreformed Cambridge, pp.68-72, depends heavily for evidence of low standards on the polemical pamphlet of Philotheologus, Letter to John Lord Bishop of Bristol. Searby, pp.263-4, follows Winstanley and the mention of 'reformers' refers to Philotheologus alone. The identity of Philotheologus is not known but he was a resident member. His pamphlet, Letter to John Lord Bishop of Bristol, should be understood more broadly in the context of ongoing attempts by Oxford and Cambridge to assert their value and superiority over Scottish and continental universities, for which see Asa Briggs 'Oxford and its Critics, 1800-1835', in The History of the University of Oxford: Nineteenth Century Oxford, Part 1 ed. M.G. Brock and M.C. Corthoys (Oxford, 1997) i. 134-145.

${ }^{11}$ Vindicator, Morning Chronicle, 24 August 1825 (Issue 175556), 1. This was cited by Samuel Perry, An Inquiry into the true spirit and intent of the ten-year divinity-statute ... (1825), pp.44-5. In terms of style and tone, Vindicator seems unlikely to have been Perry.

12 Thomas Hartwell Horne, Reminiscences Personal and Bibliographical (1862), pp.29-34.

${ }^{13}$ B. W. Young, 'Bayley, Cornelius (1751-1812)', Oxford Dictionary of National Biography, Oxford University Press, 2004 [http://www.oxforddnb.com/view/article/1748, online edn, accessed 30 Sept 2014]; Venn, Al. Cant.

${ }^{14}$ G. C. Boase, 'Hewlett, John (1762-1844)', rev. H. C. G. Matthew, ODNB, online edn, [http://www.oxforddnb.com/view/article/13154, accessed 30 Sept 2014]; J.A. Venn, Alumni Cantabrigienses. ${ }^{15}$ Henry Bradley, 'Bosworth, Joseph (1787/8-1876)', rev. John D. Haigh, ODNB [http://www.oxforddnb.com/view/article/2955, accessed 30 Sept 2014]. For an explanation of the exercises he performed and his motivation for enrolling see his letter to William Whewell, 20 March 1858, Trinity College Cambridge, Add.Ms.a/201/56. Other linguists include Coptic scholar Henry Tattam, see Thompson Cooper, 'Tattam, Henry (1788-1868)', rev. Chris Pickford, ODNB,

[http://www.oxforddnb.com/view/article/26994, accessed 30 Sept 2014] and William Barnes, see Chris Wrigley, 'Barnes, William (1801-1886)', ODNB [http://www.oxforddnb.com/view/article/1475, accessed 30 Sept 2014]. For historians see Elizabeth Baigent, 'Oliver, George (1782-1867)', ODNB,

[http://www.oxforddnb.com/view/article/20722, accessed 30 Sept 2014]; Alan Bell, 'Raine, James (17911858)', ODNB, [http://www.oxforddnb.com/view/article/23023, accessed 8 Oct 2014] (but which omits mention of admittance to Cambridge in 1816). 
${ }^{16}$ R. E. Anderson, 'Hellins, John (d. 1827)', rev. Adrian Rice, ODNB

[http://www.oxforddnb.com/view/article/12873, accessed 30 Sept 2014].

${ }^{17}$ Elizabeth Baigent, 'Scoresby, William, junior (1789-1857)', ODNB

[http://www.oxforddnb.com/view/article/24854, accessed 30 Sept 2014].

18 Philotheologus had heard 'hints' of a new examination in 1825, Letter to John Lord Bishop of Bristol, pp.17-

18. It was probably introduced by Regius Professor John Kaye (1816-17), see Report of H.M. Commissioners appointed to inquire into ...the University and Colleges of Cambridge (Parl. Papers 1852-3 [1559], xliv), p.30, and Winstanley, Early Victorian Cambridge (Cambridge, 1940), p.167. However, Winstanley also thought Kaye's successor (Thomas Turton, 1827-42) might have introduced it, Winstanley, Unreformed Cambridge, p.71. The University Calendars mention it only from 1831.

${ }^{19}$ Concerns about low undergraduate standards saw the introduction of an elementary test, known as the Previous Examination, from Lent term 1824, Searby, pp.166-167.

${ }^{20}$ For a discussion of the education of the post-reformation clergy see Rosemary O'Day, The English Clergy: The Emergence and Consolidation of a Profession, 1558-1642 (Leicester, 1979), pp.126-143.

${ }^{21}$ Winstanley, Unreformed Cambridge, pp.69, 354 n.91.

${ }^{22}$ The first Cambridge University Calendar, although dated 1796, gives data from 1795. No calendar was produced in 1798. The early volumes offer some challenges for prosopographical research: first names are not given and the data was taken directly from college boards, rather than supplied and validated by college officials. Since the colleges did not uniformly categorise their students or consistently place ten-year men on their boards, careful reconstruction is needed.

${ }^{23}$ Graduati Cantabrigienses gives alphabetical lists of members proceeding to degrees and annual tables of degrees awarded. The editions by Joseph Romilly (Cambridge, 1856) and Henry Luard (Cambridge, 1873) have been used.

${ }^{24}$ J.A. Venn, Alumni Cantabrigienses, part 2, (6 vols., Cambridge, 1940-1954) draws on many sources. It has been used to identify ten-year men who entered before the calendars begin but who did not take degrees. Note that Venn does not always recognised, or consistently identify, ten-year men. I would also like to express my gratitude to the archivists and librarians of the following colleges who have answered queries: Christ's College; Clare College; Corpus Christi College; Emmanuel College; King's College; Magdelene College; Peterhouse; Elizabeth Ennion-Smith at St Catharine's College; Tracey Deakin, Fiona Colbert and Naomi Herbert at St John's College; and Trinity College. 
${ }^{25}$ Average decadal admissions: $1770 s-7.5 ; 1780 s-7.9 ; 1790 s-3.8 ; 1800 s-4.6 ; 1810 s-18.3 ; 1820 s-25.6$ $1830 s-11.9 ; 1840 s-15.7 ; 1850 s-10.4$.

${ }^{26}$ For a general discussion of classification struggle see Elliott B. Weininger, 'Pierre Bourdieu on Social Class and Symbolic Violence' in Approaches to Class Analysis ed. Erik Olin Wright (Cambridge, 2005).

${ }^{27}$ Hampshire Record Office, 21M65/E1/4/2527.

${ }^{28}$ John Scott, The Life of the Rev. Thomas Scott, $2^{\text {nd }}$ ed. (1822), p.50. It may even be that the 1822 publication of Scott's biography contributed in a small way to the bumper matriculations in that year.

${ }^{29}$ For university recruitment see, Searby, pp.60-63; J.A. Venn, 'Matriculations at Oxford and Cambridge, 15441906', The Oxford and Cambridge Review, 3 (1908), 16 and graph; Powell and James Heywood, 'Statistics of the Universities of Oxford and Cambridge', Quarterly Journal of the Statistical Society of London, 5 (1842), 235244. Matriculations began to increase a few years before the end of the war resulting, in part, from general demographic increase, the expansion of the middle classes and, possibly, as the result of some limited university reform.

${ }^{30}$ Frederic Somers, a potential ordinand, explained that officers could remain on half-pay only if they took orders before Dec. 1824, B.I., Ord.P.1824 (unsuccessful candidates).

${ }^{31}$ Montague John Wynyard (den 1815, pr 1816, admitted 1817, CCEd person ID: 116344); Rishton Robinson Bailey (den and pr 1813, admitted 1820, CCEd Person ID: 111067); Hodgson Richard Shepherd (den 1820, pr 1821, admitted 1823, CCEd Person ID: 115203); Alexander R.C. Dallas (den and pr 1821, admitted 1821, CCEd Person ID: 26212); William Bettridge (dcn July 1824, pr 1825, admitted June 1824, B.I. Ord.P.1824, CCEd Person ID: 130844); Charles Frederick Watkins (den Feb. 1818, priest 1818, admitted Jan. 1818, CCEd Person ID: 87092); John Hobart Caunter (den 1824, pr 1827, admitted 1817, CCEd Person ID: 116658). A few others may have served in the army or navy but have retired before the war's end. (Those few who served with the East India Company's armies have been excluded.) Where possible, when referring to clergy, references have been given to the Clergy of the Church of England Database 1540-1835 (CCEd), at <http://theclergydatabase.org.uk/>. Dates of admittance are taken from Venn, Al. Cant., occasionally corrected using C.U.C.

${ }^{32}$ C.U.C. 1797, p.87. Full orders means having been ordained both deacon and priest.

${ }^{33}$ C.U.C. 1802, p.xi.

34 This was noted in Quarterly Theological Review, 2 (1825), p.373. 
${ }^{35}$ Gentleman's Magazine, 119, (March 1816), 200.

${ }^{36}$ [John M.F. Wright], Alma Mater, ii. 125n. A brace of Cantabs, Gradus ad Cantabrigiam, (1824), pp.107-8, made no mention of their being in, or intending to receive, orders. The 1803 edition of this work omitted mention of ten-year men suggesting that at the turn of the century they were too insignificant for notice.

${ }^{37}$ Ordination data has been taken from CCEd, supplemented by Crockford's Clerical Directory, 1865, ordination lists published in periodicals, archival lists and finding aids (online, printed and typescript) and numerous diocesan manuscript sources. Dates of university admission have been taken from C.U.C. and Venn, Al. Cant.

${ }^{38}$ Based on those whose clerical status at admission is known.

${ }^{39}$ The distinction between the latter two groups cannot be drawn precisely since some classed as aspirant laymen men may have had well-laid plans for ordination which fell through unexpectedly. Some of those ordained very soon after entry may have regarded themselves as unexpectedly fortunate.

${ }^{40}$ Thomas Scott found he could not spare the expense of just over 4 guineas a year after he had a family, Scott, Life of Scott, pp.50-1. Calculating the full costs of taking a degree is complicated but for the various university and college fees see C.U.C.

${ }^{41}$ F.R. Raines, Miscellanies: being a selection from the poems and correspondence of the Rev Thomas Wilson (Manchester, 1857), pp. liii-liv. He entered Trinity College in 1779 before the three terms residence requirement was introduced and kept a residence of only five weeks to complete his exercises.

${ }^{42}$ Canon 41 of the 1604 Canons. The B.D. degree was a higher degree than the M.A. and would qualify a man to hold in plurality, although holding multiple benefices was never a right and operated under numerous restrictions.

${ }^{43}$ Scott, Life of Scott, pp.50-51.

${ }^{44}$ James Kelly, 'O'Beirne, Thomas Lewis (1749-1823)', ODNB [http://www.oxforddnb.com/view/article/20438, accessed 6 Oct 2014].

${ }^{45}$ Note that whilst the numbers of graduate ordinands did increase in the $1810 \mathrm{~s}$, a surge in demand meant that they actually formed a smaller proportion of new clergy than in previous years and that non-graduates were still ordained in significant numbers. This was, however, not clear at the time. For recruitment in this period see Sara Louise Slinn, 'Non-graduate entrants to the Anglican clerical profession, 1780-1839: routes to ordination', Ph.D. thesis, University of Nottingham, 2014, pp.44-7, 82-4, 96-103, 107-112.

${ }^{46}$ Bishop Thomas Burgess's plans for a college for St David's diocese were being articulated from about 1804 although the college at Lampeter did not open until 1827. 
${ }^{47}$ The opening of St Bees College in 1817 received a great deal of national notice, not least because the motivations of the college's patron, the Earl of Lonsdale, came under close scrutiny, for which see Peter J. Manning, Reading Romantics (New York, 1990), pp.285-289.

${ }^{48}$ Encouragements to study were not unusual in bishops' and archdeacons' charges. However, concerns about keeping pace with levels of general education are particularly common at this period, see for instance: Thomas Burgess, A Charge Delivered to the Clergy of the Diocese of Salisbury ... August 1826 (1828), pp.12-13; John Headlam, A Charge Delivered to the Clergy of the Archdeaconry of Richmond (1827), pp.10-14; William van Mildert, 'A Charge Delivered Clergy of the Diocese of Durham, 1827', in William van Mildert, Sermons on Several Occasions ... (Oxford, 1838), pp.519-21; John Banks Jenkinson, A Charge delivered to the Clergy of Diocese of St Davids .... 1828, (London, 1828), pp.30-35; Charles James Blomfield, A Charge Delivered to the Clergy of his Diocese ... 1830 (1830), pp.33-4; John Kaye, 'A Charge Delivered at the Triennial Visitation in 1831', in John Kaye, Nine Charges delivered to the Clergy of the Diocese of Lincoln ... (1854), pp.66-70; James Henry Monk, A Charge to the Clergy of the Diocese of Gloucester ... 1832 (1832), pp.23-6.

${ }^{49}$ Gent. Mag., 138, (Nov. 1825), 461.

${ }^{50}$ The English and Welsh bishops only recognised degrees from universities operating within the Established Church although there was a persistent, but not universal, prejudice against Dublin and Durham graduates, see An Associate of King's College, Theological colleges: and the admission of "literates" into the ministry of the Church of England (1866), p.8. Ordinands with degrees from Scottish or continental universities were almost always treated as non-graduates.

${ }^{51}$ A Yorkshire Incumbent [William Snowden], The Church: The Case of 'Non-Graduate Clergymen', usually called 'literates', dispassionately considered... (1830), pp.3-7, 37.

52 Lincolnshire Archives, DIOC/COR/B/5/14/1/13, J. Grisdale to Bishop Kaye (with draft reply), 27 Sept., 1827.

${ }^{53}$ He did not proceed to his degree having been awarded a Lambeth B.D. in 1829, probably in recognition of his service as an authorised clerical tutor for York ordinands, see Sara Slinn, 'Archbishop Harcourt's recruitment of literate clergymen: part 2. Clerical seminaries for literates in the diocese of York, 1800-1849', Yorkshire Archaeological Journal, 81 (2009), 299-300.

${ }^{54}$ In the period 1817-1839, I have found only 13 instances of St Bees men ordained in dioceses outside the northern province.

557 St Bees and 1 St David's college alumni were admitted as ten-year men after ordination, 6 of these in the period 1831-7, The Saint Bees College Calendar for the year 1858 (1858), Venn, Al. Cant. 
${ }^{56}$ Samuel Perry, A Letter to the Public Orator of Cambridge University on the Ordination of Non-Graduates under the ten year Divinity Statute... (1825). This was replied to by Philotheologus, A Letter to the Rt Revd John, Lord Bishop of Bristol, respecting the additional examination or total abolition of ten year men in the University of Cambridge to which are added observations on Mr Samuel Perry's letter... (Cambridge, 1825). Perry's reply is A letter to His Royal Highness the Duke of Gloucester ... on the necessity of an enquiry into the conduct of the Lord Bishop of London [William Howley] towards the ten-year men of that University, (1825), and also,

following an unfavourable review, An inquiry into the true spirit and intent of the ten-year divinity-statute, with observations on the conduct of Dr. Burrows, the editor of the Theological Review... (1825). Reviews of the various pamphlets appeared in the Quarterly Theological Review, 2 (1825), 113-117, 368-374; Gent. Mag., 138 (1825), supplement 608-609 and Monthly Critical Gazette, 2: 11 (April 1825), 466-469. There was an attempt to start a debate in the Christian Remembrancer, see vii (1825), 666. An extended correspondence on the subject appeared in the Morning Chronicle: 29 July 1825 (Issue 17534); 10 Aug. 1825 (Issue 17544); 24 Aug. 1825 (Issue 17556); 30 Aug. 1825 (Issue 17561); 3 Sept. 1825 (Issue 17656).

${ }^{57}$ Although the canon was intended to encourage and benefit scholars, at both universities the M.A. regulations during this period required little additional residence or evidence of continuing study. It did, however, necessitate the payment of college and university fees and so many of the poorer clergy did not proceed to M.A.

${ }^{58}$ For a discussion of the pre-ordination education of graduate and non-graduate clergy see Sara L. Slinn, 'Nongraduate entrants to the Anglican clerical profession, 1780-1839: routes to ordination', PhD thesis Nottingham 2014, part 2.

${ }^{59}$ Gent. Mag., 138 (1825), supplement, 608-9; Philotheologus, p.22.

${ }^{60}$ Philotheologus, p.59.

${ }^{61}$ Claude Smith Bird, Sketches from the Life of .... Charles Smith Bird (1864), p.74; Philograntus, A Letter to the Right Revered John, Lord Bishop of Bristol, Respecting an Additional Examination of students in the University of Cambridge (Cambridge, 1822), pp.11-12.

62 Searby, pp.166-167, 265-268. Whilst Oxford graduates, whose studies were primarily classical, were thought to be better prepared for their ordination examinations, Oxford too had significant problems with regard to undergraduate curriculum, assessment and discipline.

${ }^{63}$ Philotheologus, p.59. 
${ }^{64}$ R. Michell, A Letter Addressed to Lord Liverpool ... on the Catholic Question, Clerical Residence and the State of Ordination ... (1823), p.27. Such a policy had operated in the diocese of St David's for some years, see Roger L. Brown, 'A Cardiganshire Incumbent Writes to his London Relatives: Lewis Evans, vicar of LLanfihangel Glenau'-glyn, 1801-35', Ceredigion 13:4 (2000), 21; National Library of Wales, LL/0/481, LL/0/405. The policy can be understood as an attempt to prevent those who had received supported education in the diocese's specialist grammar skills from seeking posts elsewhere.

${ }^{65}$ Philotheologus, pp.51-53. The 1819 Colonial Clergy Act had already prevented men ordained for service overseas from accepting employment at home without special permission.

66 Oxoniensis, Gent. Mag., 126 (Oct. 1819), 313-4.

${ }^{67}$ See for instance Henry Kaye Bonney, The Life of Jeremy Taylor (1815), pp.2-3. Taylor, the son of a barber, is said to 'afford an illustrious example of learning and religion rising into notice and to honour by their intrinsic excellence'.

${ }^{68}$ For instance, Edmund Law, bishop of Carlisle, d. 1787 (son of curate and schoolmaster); Jonathan Shipley, bishop of St Asaph, d. 1788 (son of a stationer); Samuel Hallifax, bishop of St Asaph, d. 1790 (son of an apothecary); John Moore, archbishop of Canterbury d. 1805 (son of butcher and grazier); Richard Hurd, bishop of Worcester, d. 1808 (son of yeoman farmer); Richard Watson, bishop of Llandaff, d. 1816 (son of a poor schoolmaster); William Carey, bishop of Exeter and St Asaph, d. 1846 (son of a tradesman). For a discussion of the social mobility of bishops see William Gibson, 'The social origins and education of an elite: the nineteenthcentury episcopate', History of Education, 20:2 (1991), 95-105.

${ }^{69}$ William. T. Gibson, 'The professionalization of an elite: the nineteenth century episcopate', Albion, 23:3 (Autumn 1991), 459-482, at 482.

${ }^{70}$ For late Victorian social anxiety in literary texts see Kevin Swafford, Class in Late Victorian Britain: The narrative concern with Social Hierarchy (2007). On distain for the urban lower middle class in Victorian literary and non-literary texts see Scott Douglass Banville, 'A Mere Clerk': representing the Urban Lower-Middle-Class Man in British Literature and Culture: 1837-1910, PhD. Dissertation, Ohio State University 2005. For class status anxieties played out in the evolution of the suburbs see Lara Baker Whelan, Class, Culture and Suburban Anxiety in the Victorian Era (Abingdon, 2010). For the development of the discourse of vulgarity deployed against social mobility see Susan David Bernstein and Elsie B. Michie, Victorian vulgarity: taste in verbal and visual culture (Farnham, 2009), pp.1-11. 
${ }^{71}$ Gent. Mag., 118 (July 1815), 35. For other examples of drawn from the Gentleman's Magazine to 1815 see, William Stafford, 'Representation of the social order in the Gentleman's Magazine, 1785-1815', EighteenthCentury Life, 33:2 (2009), 64-91.

72 Oxoniensis, Gent. Mag., 126 (Oct. 1819), 313-4, quoting (with some inaccuracies) from A Church of England Man, A Letter to Richard Lord Bishop of Landaff on a Projected Reformation of the Church .... (1783), pp.18-20. ${ }^{73}$ Philotheologus, pp.22-3, 57-8.

${ }^{74}$ Gent. Mag., 138 (1825), supplement 608-9. In a similar vein Michell, p.27, talks about 'men of ruined circumstances, and bankrupt fortune.' Canon law did not prohibit the ordination of tradesmen and labourers although it was often assumed that it did. Clergy were, however, prohibited from engaging in trade after ordination. Note, however, that many non-graduate clergy would have been offended by the suggestion that had such connections, many sharing the same distain of trade and labour, see Perry, An Inquiry, p.31.

75 'Cambridge University', Morning Chronicle, 19 Aug. 1825 (Issue 175552). Mummery is never recorded as a ten-year man. C.U.C. 1821 lists him as a pensioner of St John's College and when ordained at York in 1822 he claimed S.C.L. status, B.I., Ord.P.1822.

${ }^{76}$ Philotheologus, p.8.

${ }^{77}$ For instance in W.J. Conybeare's 1853 Edinburgh Review essay, 'The Church in the Mountains', later reprinted in his collected essays, in which the non-Oxbridge clergy of Wales are described as 'uneducated peasant clergy' with 'low tastes and coarse vices of the class from which they sprung,' W.J. Conybeare, Essays, Ecclesiastical and Social (1855), p.4.

${ }^{78}$ See Anne Baltz Rodrick, 'The importance of being an earnest self-improver: class, caste and self-help in midVictorian England', Victorian Literature and Culture, v.29:1 (March 2001), 39-50.

${ }^{79}$ Geoffrey Crossick, 'From gentleman to the residuum: languages of social description in Victorian Britain', in Language, History and Class, ed. Penelope J. Corfield (Oxford, 1991), pp. 150-178, at pp. 163-166; Patricia Ingham, Language of Gender and Class: Transformation in the Victorian Novel, (1996), pp.109-111; David Canadine, Class in Britain, (2000), p.92.

${ }^{80}$ The phrase 'gentleman heresy' originated with Hurrell Froude. He did not articulate the idea in print during his life although he was thinking along these lines c.1833-4, see Louise Imogen Guiney, Hurrell Froude:

Memoranda and Comments (1904), pp.118, 150, 243, 248. The phrase appeared in print in Remains of the Late Rev. Richard Hurrell Froude, (2 vols., 1838), i. 404, and can be found in the periodical press during the 1850s and 1860s. 
${ }^{81}$ Brian Heeney, A Different Kind of Gentleman (Hamden, CT., 1976), pp.22-23.

82 Venn, Al. Cant.; CCEd Person IDs 67036 (Hutchinson); 113299 (Gregory); 10455 (Curtis).

${ }^{83}$ Horne, p.35.

${ }^{84}$ Venn, Al. Cant.; CCEd Person IDs 417 (Pearson); 405 (Owen. N.B. CCEd gives the date of a letter dimissory).

858 such entrants have been identified 1770-1809.

${ }^{86} 1810 s-20 \% ; 1820 s-20 \% ; 1830 s-28 \% ; 1840 s-34 \% ; 1850 s-24 \%$.

${ }^{87}$ Perry, An Inquiry, p.34.

${ }^{88}$ Lincolnshire Archives, DIOC/COR/B/5/14/1/37, 9 Nov. 1837. The unnamed bishop of Lichfield is described as 'the late' - Ryder died March 1836.

${ }^{89}$ Lincolnshire Archives, DIOC/COR/B/5/14/6, 3 July 1834. Kaye was head of Christ's College, 1814-1830, Regius Professor of Divinity, 1816-1827, bishop of Bristol (1820-27), and then of Lincoln (1827-53). These multiple roles lead to him being contacted for advice by men experiencing difficulties getting ordained, see DIOC/COR/B/5/14/. For his correspondence with Perry see DIOC/COR/B/ 5/14/7.

${ }^{90}$ Arthur Quiller-Couch, Poet as Citizen and other Papers (Cambridge, 1934), pp.174-5. C.U.C. 1829, p.21.

${ }^{91}$ Philotheologus, pp.24-25, protested about the devaluation of the B.D., but there were other reasons for its unpopularity among fellows. For a contemporary view see Morning Chronicle, 24 Aug. 1825 (Issue 17556).

${ }^{92}$ For example, 1809-1828, Peterhouse: B.D. $£ 3$ 17s 0d., 10-year BD $£ 11$ 7s 0d.; Magdalene College: B.D. $f 1$ 1s Od., 10-year B.D. $f 17$ 1s 0d. In 1826 Trinity College raised 10 -year B.D. fees from $f 1$ 14s $10 \mathrm{~d}$ to $f 10$ ss $4 d$ which seems to have been related to a desire to ensure that ten-year men paid an amount that compensated the college for the fees they had not paid for their omitted B.A. and M.A. degrees. (Cambridge, Trinity College, Bursar's Minute Book, 14 Dec. 1825, 8 . I would like to offer my thanks to one of the anonymous reviewers for this reference.) Fees at Trinity Hall were also high ( $€ 1616 \mathrm{~s} 0 \mathrm{~d})$ but not higher than the standard B.D. For fee regimes see C.U.C.

${ }^{93}$ The cheapest colleges for ten-year men were Trinity ( $£ 14$ s. 10d.), Queens ( $\left.f 215 s .0 d.\right)$ and St Johns ( $£ 3$ 0s. Od.). Some fellows at Queens and St Johns were required by statute to take B.D.S., C.U.C.

${ }^{94}$ Winstanley, Unreformed Cambridge, 355 n.95. For instance, Thomas Homer (admitted 1815), Edward Edwards (admitted 1816); George Morss Jukes (admitted 1816); John Worgan Dew (admitted) 1822, Richard William Morice (admitted 1823), Dionysis Tucker (admitted 1824), John Flowerdew Colls (admitted 1826), Venn, Al. Cant. 
95 Of laymen who were successful in getting orders, Trinity took 10 (none after 1826), Queens, 28, and St John's, 46. To these should be added men who were admitted as laymen and do not ever seem to have taken orders: Trinity, 16, Queens, 15 and St Johns, 63.

${ }^{96}$ For a discussion of the ways non-graduates were educated for the Church see Slinn, 'Non-graduate entrants to the Anglican clerical profession', chapters 4 and 5.

${ }^{97}$ Lincolnshire Archives DIOC/COR/B/5/14/4, letter dated 12/9/1833. Skinner, who had eighteen years of teaching experience, appears to have decided that the ten-year route offered him no advantage.

${ }^{98}$ Nicholas Carlisle, A Concise description of the Endowed Grammar Schools of England and Wales (2 vols., 1818), i. 408.

${ }^{99}$ Perry detailed his predicament in a series of printed pamphlets, see above, and in his correspondence with bishop Kaye, Lincolnshire Archives DIOC/COR/B/ 5/14/7.

$1001810 s-22 ; 1820 s-36 ; 1830 s-22 ; 1840 s-44 ; 1850 s-21$. The numbers of unsuccessful men might be slightly high for the 1840 s and 1850 s since consolidated ordinations records are lacking for this period, CCEd ending in 1836 and Crockford's Clerical Directory not beginning until 1858. Extensive use has, however, been made of ordination lists in periodicals and diocesan archive material.

101 John William Gill (als. Gile) of Sidney Sussex College was ordained for Bristol only a few months after he was admitted in 1814, (CCEd Person ID 41081). Schoolmaster Archibald Smellie of St John's College was ordained at Norwich in 1816 (CCEd Person ID 115306).

102 Ten-year men from St John's College, who never took orders: $1810 s-7 ; 1820 s-13 ; 1830 s-9 ; 1840 s-18$; $1850 s-14$.

10343 laymen entered St John's as ten-year men 1814-1858 who were later ordained.

${ }^{104}$ Venn, Al. Cant.; CCEd Person ID 67076.

105 For instance Alexander Power, admitted as ten-year man 1821, readmitted 1823, B.A. 1827, deacon for Canterbury 1826; Thomas Gurney, admitted as ten-year man 1822, readmitted 1828, B.A. 1832, deacon for Ely 1833; John Vaughan, admitted 1820, readmitted 1821 and 1825, L.L.B. 1828, deacon at Bristol 1828; Francis Merewether, admitted 1825, L.L.B. 1832, deacon 1829, Venn, Al. Cant.; CCEd. Men studying law were considered to be of B.A. status once they were of S.C.L. status, about three years after matriculation and several years before taking their L.L.B. degrees.

106 Thomas Radcliffe was admitted to Christ's in 1821 and St Bees in 1822. After ordination at York in 1823 he removed his name from the boards showing that his primary intention had been to qualify himself for 
ordination rather than take a degree. John Flowerdew Colls was admitted to Trinity College as a ten-year man in 1826, to St Bees in 1829, and was ordained at York in 1831. Samuel Hyde Godmond was admitted to St Catharine's in 1831 and St Bees in 1835 (he probably never took orders). John Pemberton Bartlett was admitted to Christ's in 1839 and St Bees in 1845, and was ordained deacon at Peterborough in 1847. Venn, Al. Cant.; CCEd, St Bees College Calendar 1858.

107 The issue was, however, raised by a reviewer, The Monthly Critical Gazette, 2:11 (April 1825), 466-69.

${ }^{108}$ London Metropolitan Archive DL/A/B/002/MS10326/. The non-graduate referred to by Perry and Philotheologus is Thomas Hartwell Horne, see Horne, Reminiscences, p.35.

${ }^{109}$ See for instance, The Monthly Critical Gazette, 2:11 (April 1825), 466-69. Most notorious was bishop Herbert Marsh's (Peterborough 1818-1839) attempts to exclude ordinands with high Calvinistic leanings which lead to vigorous pamphleteering in $1820-22$ and a petition to the House of Lords.

${ }^{110}$ Perry published a number of other pamphlets including some which, despite their titles, concern the tenyear statute: A Letter to the King's Ministers on the Project ... for converting our Cathedral Establishments into Supplementary Institutions for remedying the present defects in clerical education in our Universities ... (1826); A Letter ... concerning the Catholic Question, ([1828]); A Letter to the King .... on the necessity of a sound and constitutional Church Reformation ... (1833); An Address to the British Imperial Parliament on that part of the ecclesiastical commissioner's report which relates to pluralities, non-residence, and stipendiary curates ... (1836).

${ }^{111}$ Q.T.R. 2, 370, 374.

112 In 1841 he was still a schoolmaster living in Shenfield, Essex, with a wife, 13 younger Perrys, and 16 boarding pupils, The National Archive of the UK, Census Returns for 1841, piece 322, book 28, folio 8. 113 TNA: will of Samuel Perry, proved 12 Feb. 1846, Prob. 11, piece 2031, vol. 3, f. 245v-248v, includes a declaration about the alteration by the executor.

${ }^{114}$ Samuel Gideon Frederick and Alfred John Perry, Venn, Al. Cant.

${ }^{115}$ George Atkinson entered in 1828, at the recommendation of an archbishop and the bishop of Lichfield, Venn, Al. Cant.; Lincolnshire Archives, DIOC/COR/B/5/14/1/37 (letter dated 9 Nov. 1837). ${ }^{116}$ Perry, A Letter ... concerning the Catholic Question, p.3; Perry, Letter to the King ... necessity of a ... Constitutional Church Reformation, $2^{\text {nd }}$ ed. (1833), p.12.

${ }^{117}$ Political Examiner, 10 Sept. 1837 (Issue 1545), 1.

${ }^{118}$ Peacock, p.150 n.2. 
${ }^{119}$ For the university's weak response to external pressure to reform, and for the background to the Revising Syndicate (1849-1853) , the Graham Commission (1850 - 1852), and the Cambridge University Act of 1856 see Searby, pp.507-544. Joseph Romilly, Registrary of the university, recorded that the syndicate appointed to revise the statutes had difficulty reaching agreement on the subject of ten-year men in 1852, M.E. Bury and J.D. Pickles, Romilly's Cambridge Diary, 1848-1864 (Cambridge, 2000), p.120.

${ }^{120}$ Cambridge University Commission, (Parl. Papers 1852-3, [1559], xliv), p.31.

${ }^{121}$ Venn, Al. Cant.

${ }^{122}$ Cambridge University Commission, pp.31-2. Durham had established a Licence in Theology (L.Th) in 1833, F.W. Bullock, A History of Training for the Ministry of the Church of England, 1800-1874 (St Leonards-on-Sea, 1955), p.63. From 1846 King's offered a two year theological Associateship (the theological AC.K.), David Dowland, Nineteenth-Century Anglican Theological Training: The Redbrick Challenge (Oxford, 1997), pp.47-51. ${ }^{123}$ Cambridge University Commission, pp.30-1

${ }^{124}$ Cambridge University Commission, pp.145-9, 184-5. For concerns about barriers to access at Oxford University see James Heywood, The Recommendations of the Oxford University Commissioners (1853), pp.197212.

${ }^{125}$ Five years after priesting alumni could be examined for a B.D., D.T.W. Price, $A$ History of Saint David's University College, Lampeter (2 vols., Cardiff, 1977), i. 88.

${ }^{126}$ Evidence Taken Before the Durham University Commissioners, 1861, (Parl. Papers 1863 [77], xlvi), appendix 9, p.129.

${ }^{127}$ For a summary of discussions see Bullock, pp.129-41. For attempts by non-graduate training colleges to deal with the inferior status of their students see, Dowland, pp.171-174.

${ }^{128}$ For a summary see Asa Briggs, 'Oxford and its Critics'.

${ }^{129}$ For the controversy see Owen Chadwick, The Victorian Church, $2^{\text {nd }}$ edn. (2 vols., 1970) i. 89-95, 480-1, ii. 443.

${ }^{130}$ The Clarendon Commission (1864) appropriated the endowments of certain schools to established a separate class of public schools for the elite. The Taunton Commission (1868) allowed endowed free-grammar schools to focus on fee-paying middle class education and make curriculum changes in response to this market. The Newcastle Commission (1861) dealt with provision of basic education for the masses. See also Rosemary Jann, 'Breeding, Education and Vulgarity: George Gissing and the lower-middle classes' in Victorian Vulgarity, pp.85-100, at 88-90. 